\title{
Modulation of Oxidative Stress Associated with Experimentally-Induced Benign Prostatic Hyperplasia in Rats by Zapoteca portoricensis Root Extracts ${ }^{\dagger}$
}

\author{
Ikeyi Adachukwu Pauline ${ }^{1,2, *}$, Okagu Innocent Uzochukwu ${ }^{2}$ and Igwe Nonyelum Christiana ${ }^{3}$ \\ Published: $30^{\text {th }}$ November, 2020 \\ 1 Institute of Management and Technology, Enugu 400271, Nigeria; adachukwuikeyi@gmail.com \\ 2 Medical Parasitology, Toxicology and Drug Discovery Unit, Department of Biochemistry, University of Nigeria, \\ Nsukka 410001, Nigeria; innocent.okagu@unn.edu.ng \\ 3 Department of Pharmaceutical Chemistry, Faculty of Pharmacy, University of Nigeria, Nsukka 410001, Nigeria; \\ igwe.christiana@yahoo.com \\ * Correspondence: adachukwuikeyi@gmail.com; Tel.:+2349019813440 \\ + Presented at the 1st International e-Conference on Antioxidants in Health and Disease, 01-15 December 2020; \\ Available online: https://cahd2020.sciforum.net/.
}

\begin{abstract}
Background: The existence of oxidative stress in the pathogenesis of benign prostatic hyperplasia $(\mathrm{BPH})$, characterized by elevation in markers of oxidative stress/lipid peroxidation (8-hydroxyguanosine, malondialdehyde and 8-hydroxynonenal) and reduction in antioxidant status (catalase, superoxide dismutase, glutathione peroxidase and reduced glutathione) is scientifically documented. We hypothesize that a good treatment regimen for $\mathrm{BPH}$ should return the pro-oxidant/antioxidant status to normal; hence, pro-oxidant/antioxidant status is an indirect indicator of treatment response. In this study, the effect of crude methanol extract (CME) of Zapoteca portoricensis root and its methanol (MF) and ethyl acetate (EAF) fractions on the pro-oxidant/antioxidant status of experimentally-induced BPH was investigated. Methods: Forty-five Wistar albino rats (7 weeks, 180-200 g) used in this study were divided into nine groups $(n=5)$. Group 1 served as normal control. BPH was induced in groups $2-9$ by daily subcutaneous administration of dihydrotestosterone $(400 \mu \mathrm{g} / \mathrm{mL}) \mathrm{and}$ estradiol $(80 \mu \mathrm{g} / \mathrm{mL})$ for 28 days. Group 2 served as BPH-control (was left untreated) while group 3 received dutesteride (Avodart ${ }^{\circledR}$ ). Groups 4 and 5, 6 and 7, and 8 and 9 received, by gavage 200 and 400 $\mathrm{mg} / \mathrm{kg} / \mathrm{d}$ b.w. of CME, 200 and $400 \mathrm{mg} / \mathrm{kg} / \mathrm{d}$ b.w. of $\mathrm{MF}$, and 200 and $400 \mathrm{mg} / \mathrm{kg} / \mathrm{d}$ b.w. of EAF, respectively for 14 days. Results: There were increased prostatic specific (PSA) and malondialdehyde but reduced antioxidant status in BPH-control relative to normal control. At $400 \mathrm{mg} / \mathrm{kg} / \mathrm{d}$ b.w, CME, MF and EAF decreased prostatic specific antigen by 55.91\%, 57.54\% and 56.75\%, respectively comparable to $58.80 \%$ by dutesteride. In addition, the results of histological assessment of prostate tissues of the experimental rats fed extracts demonstrate an improved prostate status. Conclusion: The extracts returned the pro-oxidant/antioxidant status modified by BPH to normal. These findings may justify the plant's folkloric use and suggest that extracts can be exploited further as potential source of entities for managing $\mathrm{BPH}$.
\end{abstract}

Keywords: Zapoteca portoricensis; prostatic specific antigen; benign prostatic hyperplasia; oxidative stress; antioxidant

\section{Introduction}

Benign prostatic hyperplasia (BPH) also called benign enlargement of the prostate (BEP) or prostate Adenoma, is a common event in aging and constitutes a lot of health burden and prevalent among aging 
The 1st International Electronic Conference on Antioxidants in Health and Disease, 1-15 December 2020

males It is a multi factorial disease characterized by a non-malignant, uncontrolled proliferation of the smooth muscles, stromal and epithelial cells within the transition zone of the prostate gland. The etiology is not clear so far, however, it is the commonest non-cancerous form prostate cell growth and initial development usually after 40 years of age with $\sim 40 \%$ of males [2-5]. Prevalence statistics is well documented in the developed world but not so in Africa, especially Nigeria A variety of factors chiefly age, genetics, lifestyle, hypertension, obesity, diabetes and insulin resistance have been linked to the development of BPH The prostate, an exocrine gland found in the male reproductive system, produces, secretes and controls the flow of seminal fluid expelled at the time of sexual climax together with the spermatozoa The testosterone metabolite- Dihydroxytestosterone (DHT) and oestrogen are believed to play a role in the etiology of BPH. Studies have shown that as men age the active testosterone in the blood decreases leaving a higher proportion of estrogen. Thus, the accumulation DHT in the prostate gland encourages the growth of prostate cells. In addition, the development of BPH, an age dependent disease, has been associated with increased lipid peroxidation, oxidative stress, inflammatory process and decreased levels of antioxidants. Studies have shown an increased malondialdehyde (MDA) levels, a product of lipid peroxidation and an indicator oxidative stress, a decrease in serum levels of antioxidants such as glutathione (GH) glutathione peroxidase(GSH-Px), and glutathione reductase(GR), Superoxide dismutase (SOD) and non-enzymatic antioxidants- vitamins $C$ and $E$, in the plasma and erythrocytes The use of surgical procedures, alpha-blockers/adrenoceptor antagonists (Terazosin and Doxazosin), 5-alpha-reductase inhibitors (finasteride and dutasteride) and some forms of combination therapies in the management of BPH achieve reduction in mass of the prostate gland or relaxation of the muscle tone The associated side effects cost and risks of surgery however, have led to increased search for alternatives in managing this disease. Antioxidants therapy and plant-derived dietary polyphenolic compounds, such as flavonoids with cancer cells and chemo preventive potential seems to be a promising therapy Phyto-therapeutic preparations most commonly used in BPH include 5-beta- sterol from Hypoxis roperi (African star grass), Pygeum from Prunies africanum, the roots of Urtica dioica and Serenoa repens from Saw palmetto [12-14]. Zapoteca portericensis (jacq), HM Hernandez (Fabaceae) is a perennial seasonal shrub and a native of West Africa, West Indies and the Atlantic coast of America. The peoples of eastern and southern Nigeria have found the different plant parts useful in traditional medicinal practices [15] for diarrhea, convulsion and tonsillitis [16,17]. Its antiulcer, antimicrobial and anti-inflammatory activities have been reported. The root extracts have been shown to have trypanocidal activity against trypanosome brucei rhodensiense Reported phytochemical analysis of the root and other plant parts indicated the presence phytochemicals such as saponins, resins, glycosides, flavonoids, alkaloids, terpenoids and steroids The traditional use of Zapoteca portoricensis root extract in the management of microbial and inflammatory disorders and its folkloric use in the management of BPH motivated this study.

\section{Methods}

Plant materials:

The roots of Zapoteca portoricensis were collected from Orba and Eha-Alumona, in Nsukka zone of Enugu state, Nigeria. The roots were identified and authenticated by Mr. A. Ozioko of the Bioresource development and Conservation Program (BDCP) Research Centre Nsukka, Enugu state, Nigeria. The root samples were air dried for three weeks to constant weight at room temperature $\left(29^{\circ} \mathrm{C}-35^{\circ} \mathrm{C}\right)$ and ground into uniform coarse form using a milling machine. The methanolic extract was prepared by soaking $2000 \mathrm{~g}$ of dried pulverized roots samples in $1.5 \mathrm{~L}$ of methanol for $72 \mathrm{~h}$. It was filtered using Whatman Number 4 filter paper and the filtrate was concentrated using Rotary evaporator at regulated temperature. The methanol extract obtained was fractionated by column chromatography using $1.3 \mathrm{~L}$ of methanol and $1.3 \mathrm{~L}$ of ethyl acetate as solvents.

Animals: 
The 1st International Electronic Conference on Antioxidants in Health and Disease, 1-15 December 2020

Adult male rats Wistar strain (80-120 g) obtained from the animal holding unit of the Department of Zoolgy and Environment Biology, University of Nigeria, Nsukka were used in the study. The animals were housed under standard conditions $\left(25 \pm 2{ }^{\circ} \mathrm{C}\right.$ and $12 \mathrm{~h}$ light/dark cycle). The rats were fed twice daily with standard pellets (Grand Cereals Ltd., Enugu Nigeria) and had unrestricted access to clean drinking water. The guide for the care and use of laboratory animals procedures were followed in this study [20].

\section{Experimental Design-Animal Grouping}

For this study, Forty five male albino rats divided into nine groups of five rats each representing groups receiving different doses of crude methanol extract, methanol and ethyl acetate fractions of the plant root sample. Group 1 is the normal control (Not induced and untreated), Group 2 is the positive control (Induced and Untreated), and Group 3 is the standard control (induced and treated with standard drug, Dutesteride/Avodart). Groups 4 and 5 were induced with BPH and treated with $200 \mathrm{mg} / \mathrm{kg}$ and 400 $\mathrm{mg} / \mathrm{kg}$ body weight of crude methanol extract respectively. Groups 6 and 7 were induced with BPH and treated with $200 \mathrm{mg} / \mathrm{kg}$ and $400 \mathrm{mg} / \mathrm{kg}$ body weight of methanol fraction respectively. Groups 8 and 9 were induced with BPH and treated with $200 \mathrm{mg} / \mathrm{kg}$ and $400 \mathrm{mg} / \mathrm{kg}$ body weight of ethyl acetate fraction respectively.

\section{Induction of Benign Prostatic Hyperplasia (BPH)}

Experimentally developed BPH model was created in the male Wistar rats by subcutaneous administration of dihydrotestosterone (DHT) and estradiol (300 $\mu \mathrm{g} / \mathrm{mL}$ and $80 \mu \mathrm{g} / \mathrm{mL}$ respectively) dissolved in olive oil for 28 days [21-23]. Before induction blood was drawn by ocular puncture for initial prostatic specific antigen (PSA) assay.

Treatment of Benign Prostatic Hyperplasia (BPH) with Plant Extracts

The crude methanol extract, methanol and ethyl acetate fractions were dissolved in tween-80 and normal saline. The dissolved standard drug, Dutasteride (Avodart) was administered orally to group 3 once daily while crude methanol extract and fractions were administered orally to groups 4-9 once daily. The treatment lasted for 14 days. At the end of the treatment with plant extracts and fractions blood was drawn by ocular puncture into clean EDTA bottles for final PSA assay and determination of biochemical parameters.

\section{Determination of biochemical indices}

The serum prostatic specific antigen (PSA) level,s expressed in $\mathrm{ng} / \mathrm{mL}$ were analysed with a PSA ELISA kit according to the manufacturer's instructions (Biocheck, Inc., South San Francisco, CA, USA. Catlog number: BC1019) while the activity of serum acid phosphatase(ACP) was assayed using the colorimetric method of Tietz [24] as outlined in Randox Kit(UK). Similarly, lipid peroxidation was estimated by measuring spectrophotometerically the malondialdehhyde (MDA) concentration as described by Wallin et al. [25], superoxide dismutase (SOD) activity was assayed by the method of Arthur and Boyne [26] as contained in the Randox Kit, UK used and the catalase (CAT) activity was assayed by the method of Sinha [27]. In addition, reduced glutathione concentration was determined by the method of King and Wootton [28] and vitamin C concentration was determined using the method of Tietz, [29].

\section{Statistical analysis}

Results were expressed as mean \pm standard deviation (SD) and test of significance was determined at $p<0.05$. Laboratory data were analysed using one-way analysis of variance (ANOVA) in Statistical Product and Service Solutions (SPSS), version 18. 


\section{Results and Discussion}

This study investigated the effect of crude methanol extract (CME) of Zapoteca portoricensis root and its fractions on PSA levels, ACP activities, the oxidative stress and antioxidant status of albino rats experimentally induced with benign prostatic hyperplasia (BPH).

Table 1. Effect of crude methanol extract and fractions of Zapoteca portoricensis roots sample on Prostatic specific antigen (PSA) of BPH induced rats.

\begin{tabular}{cccc}
\hline Group & PSA BF & PSA AF & ACP (U/L) \\
\hline Group 1 & $2.47 \pm 0.18^{\mathrm{b}}$ & $2.97 \pm 0.10^{\mathrm{e}}$ & $2.24 \pm 0.33^{\mathrm{a}}$ \\
Group 2 & $2.54 \pm 0.03^{\mathrm{a}}$ & $3.06 \pm 0.05 \mathrm{c}, \mathrm{d}$ & $3.81 \pm 0.37 \mathrm{c}$ \\
Group 3 & $2.50 \pm 0.08^{\mathrm{b}}$ & $1.03 \pm 0.07 \mathrm{a}, *$ & $2.78 \pm 0.59 \mathrm{~b}, \mathrm{c}, *$ \\
Group 4 & $2.74 \pm 0.12^{\mathrm{c}}$ & $1.15 \pm 0.04 \mathrm{~d}, *$ & $3.04 \pm 0.22 \mathrm{~b}, \mathrm{c}, *$ \\
Group 5 & $2.54 \pm 0.09^{\mathrm{b}}$ & $1.12 \pm 0.03 \mathrm{c}, \mathrm{d}, *$ & $2.91 \pm 0.20_{\mathrm{b}, \mathrm{c}, *}$ \\
Group 6 & $2.72 \pm 0.16^{\mathrm{c}}$ & $1.11 \pm 0.03 \mathrm{~b}, \mathrm{c}, \mathrm{d}, *$ & $2.71 \pm 0.15^{\mathrm{b}, \mathrm{c}, *}$ \\
Group 7 & $2.52 \pm 0.08^{\mathrm{b}}$ & $1.07 \pm 0.05 \mathrm{a}, \mathrm{b}, \mathrm{c}, *$ & $2.70 \pm 0.19 \mathrm{~b}, \mathrm{c}, *$ \\
Group 8 & $2.81 \pm 0.07^{\mathrm{c}}$ & $1.04 \pm 0.05_{\mathrm{a}, \mathrm{b}, *}$ & $2.62 \pm 0.36_{\mathrm{a}, \mathrm{b}, *}$ \\
Group 9 & $2.52 \pm 0.06^{\mathrm{b}}$ & $1.09 \pm 0.03 \mathrm{a}, \mathrm{b}, \mathrm{c}, \mathrm{d}, *$ & $2.64 \pm 0.23 \mathrm{a}, \mathrm{b}, \mathrm{c}, *$ \\
\hline
\end{tabular}

$n=5$; Data represent mean \pm SD $(n=5)$; Values with ${ }^{\star * \prime}$ are significantly different compared to BPH-control while values with letters of the alphabets ' $a, b, \ldots . n$,' as superscripts are significantly different compared to normal control $(p<0.05)$. Group $1=$ Normal control (not BPH-induced and no treatment). Group $2=$ BPH-control (BPH-induced but no treatment). Group 3 = Standard control (induced and treated with AvodartR().Groups 4 and $5=$ Induced and treated with 200 and $400 \mathrm{mg} / \mathrm{kg}$ of CME,respectively. Groups 6 and 7 = Induced and treated with 200 and $400 \mathrm{mg} / \mathrm{kg}$ of MF,respectively. Groups 8 and $9=$ Induced and treated with 200 and $400 \mathrm{mg} / \mathrm{kg}$ of EAF, respectively.

\subsection{Effect of Crude Methanol Extract and Fractions of Zapoteca Portoricensis Roots Sample on Prostatic Specific} Antigen (PSA) of BPH Induced Rats

The results obtained showed a significant $(p<0.05)$ decrease in PSA levels and ACP activities for all the test groups at different concentrations (Table 1). The decrease in PSA levels by the extract is comparable to that obtained from the standard drug-Dutesteride (Avodart). This is an indication of its protective effect against the development of $\mathrm{BPH}$. The result agrees with a recent report that treatment of $\mathrm{BPH}$-induced rats with ethanol extract of $\mathrm{Z}$. portoricensis stem has positive outcome by reducing PSA levels and prostate weight in rats PSA is generally elevated in BPH and other Prostate disorders and is a reliable marker for BPH. A reduced PSA is associated with reduced prostate hyperplasia as a direct consequence of $5^{\prime} \alpha$ reductase inhibition or anti-inflammatory action. Many plants associated with reduced $\mathrm{BPH}$ have been documented [31,32]. BPH is caused by an increase in dihydrotestosterone (DHT), a metabolite produced when testosterone is converted to DHT by an enzyme $5^{\prime} \alpha$ reductase. Consequently, inhibitors of 5- alpha reductase which block the production of DHT will slow down the development of $\mathrm{BPH}$.

Table 2. Effect of crude methanol extract and fractions of Zapoteca portoricensis roots sample on oxidative stress and antioxidant indices of benign prostate hyperplasia (BPH)-induced rats.

\begin{tabular}{cccccc}
\hline & \multicolumn{5}{c}{ Oxidative Stress and Anti-Oxidant Indices } \\
\cline { 2 - 6 } Group & MDA Conc (mg/dl) & $\begin{array}{c}\text { SOD Activity } \\
\text { (IU/L) }\end{array}$ & $\begin{array}{c}\text { Catalase Activity } \\
(\mathbf{I U} / \mathrm{L})\end{array}$ & $\begin{array}{c}\text { GSH } \\
(\mathbf{m g} / \mathbf{d l})\end{array}$ & $\begin{array}{c}\text { Vit C } \\
(\mathbf{m g} / \mathbf{d l})\end{array}$ \\
\hline Group 1 & $3.25 \pm 0.21^{\mathrm{c}}$ & $81.33 \pm 3.91^{\mathrm{e}}$ & $1.94 \pm 0.14^{\mathrm{b}}$ & $24.63 \pm 4.65^{\mathrm{b}}$ & $0.65 \pm 0.09^{\mathrm{a}}$ \\
Group 2 & $2.73 \pm 0.37^{\mathrm{b}}$ & $64.30 \pm 8.16^{\mathrm{a}}$ & $1.50 \pm 0.29^{\mathrm{a}}$ & $18.88 \pm 4.16^{\mathrm{a}}$ & $0.35 \pm 0.13^{\mathrm{a}}$ \\
Group 3 & $2.91 \pm 0.28^{\mathrm{bc}}$ & $77.16 \pm 1.99^{\mathrm{d}, \mathrm{e}, *}$ & $1.75 \pm 0.16^{\mathrm{a}, \mathrm{b}}$ & $21.37 \pm 1.13^{\mathrm{a}}$ & $0.55 \pm 0.08^{\mathrm{a}}$ \\
\hline
\end{tabular}


The 1st International Electronic Conference on Antioxidants in Health and Disease, 1-15 December 2020

\begin{tabular}{cccccc}
\hline Group 4 & $2.68 \pm 0.21^{\mathrm{b}}$ & $70.48 \pm 2.61^{\mathrm{b}, \mathrm{c}}$ & $1.53 \pm 0.11^{\mathrm{a}}$ & $18.64 \pm 1.92^{\mathrm{a}}$ & $0.43 \pm 0.09^{\mathrm{a}}$ \\
Group 5 & $2.58 \pm 0.25^{\mathrm{a}, \mathrm{b}}$ & $71.64 \pm 4.24^{\mathrm{b}, \mathrm{c}, \mathrm{d}, *}$ & $1.66 \pm 0.14^{\mathrm{a}}$ & $20.46 \pm 0.81^{\mathrm{a}}$ & $2.25 \pm 1.81^{\mathrm{a}}$ \\
Group 6 & $2.54 \pm 0.13^{\mathrm{a}, \mathrm{b}}$ & $72.47 \pm 3.10^{\mathrm{b}, \mathrm{c}, \mathrm{d}, *}$ & $1.67 \pm 0.22^{\mathrm{a}}$ & $20.22 \pm 1.70^{\mathrm{a}}$ & $0.47 \pm 0.04^{\mathrm{a}}$ \\
Group 7 & $2.71 \pm 0.25^{\mathrm{b}}$ & $74.44 \pm 2.83^{\mathrm{c}, \mathrm{d}, *}$ & $1.71 \pm 0.27^{\mathrm{a}, \mathrm{b}}$ & $57.09 \pm 6.63 \mathrm{a}$ & $0.44 \pm 0.04^{\mathrm{a}}$ \\
Group 8 & $2.18 \pm 0.16^{\mathrm{a}, *}$ & $67.58 \pm 6.38^{\mathrm{a}, \mathrm{b}}$ & $1.48 \pm 0.09^{\mathrm{a}}$ & $19.05 \pm 1.17^{\mathrm{a}}$ & $0.30 \pm 0.04^{\mathrm{a}}$ \\
Group 9 & $2.24 \pm 0.51^{\mathrm{a}, *}$ & $72.06 \pm 2.18^{\mathrm{b}, \mathrm{c}, \mathrm{d}, *}$ & $1.55 \pm 0.05^{\mathrm{a}}$ & $19.85 \pm 0.85^{\mathrm{a}}$ & $0.36 \pm 0.08^{\mathrm{a}}$ \\
\hline
\end{tabular}

$n=5$; Data represent mean $\pm \mathrm{SD}(n=5)$; Valueswith **are significantly different compared to BPH-control while while values with letters of the alphabets ' $a, b, \ldots . n$,' as superscripts are significantly different compared to normal control $(p<0.05)$.

\subsection{Effect of Crude Methanol Extract and Fractions of Zapoteca Portoricensis Roots Sample on Oxidative Stress and Antioxidant Indices of Benign Prostate Hyperplasia (BPH)-Induced Rats}

A significant $(p<0.05)$ decrease in malondialdehyde concentration, a significant $(p<0.05)$ increase in superoxide dismutase activity and a non-significant $(p>0.05)$ increase in catalase activity and glutathione concentration was observed in all the test groups. However, there was no significant difference in vitamin $\mathrm{C}$ concentration in all the test groups (Table 2). These results are indicative of the oxidative stress/lipid peroxidation and antioxidant potentials of Zapoteca portoricensis root extracts and thus its protective effect against BPH. Oxidative stress (OS)/Lipid peroxidation is considered to be one of the mechanisms that trigger the chain of reactions involved in the development and progression of prostatic hyperplasia (BPH). This is characterized by the observed increase in oxidative stress/lipid peroxidation and decreased levels of antioxidants indices. The development of $\mathrm{BPH}$, an age dependent disease, has been associated with increased lipid peroxidation, oxidative stress, inflammatory process and decreased levels of antioxidants [33-35]. In Lipid peroxidation Polyunsaturated fatty acids peroxides generate malondialdehyde (MDA) and 4-hydroxyalkanals upon decomposition This process is an established mechanism of cellular injury, and is used as an indicator of oxidative stress. Superoxide dismutase (SOD) decomposes superoxide anion into hydrogen peroxide and oxygen at very high rates. Superoxide radical is involved in diverse physiological and patho-physiological processes Catalase (CAT) is antioxidant enzymes ubiquitously present in aerobic cells and catalyses the decomposition of hydrogen peroxide to water and oxygen. High concentration of hydrogen peroxide is deleterious to cells, and its accumulation causes oxidation of cellular targets such as DNA, proteins and lipids, leading to mutagenesis and cell death [38]). Glutathione has antioxidant properties since the thiol group in its cysteine moiety is a reducing agent and can be reversibly oxidized and reduced. In cells, glutathione is maintained in its reduced form by glutathione reductase (GR), and in turn reduces other metabolites and enzymes, as well as react directly with oxidants. Vitamin C (ascorbate), a water-soluble vitamin involved in anti-oxidative processes in cellular metabolism, plays an important role in synthesis of collagen and nor epinephrine by maintaining the necessary enzymes in their active forms It is also a co-factor for the hydroxylase involved in the hydroxylation of proline residues of collagen, which is vital to wound healing It is probable that the various phytochemical constituents of the extracts, such as the flavonoids, saponins, phenols and terpenoids [41] are involved in scavenging free radicals from the tissues, thus reducing oxidative stress.

\section{Conclusions}

The extracts and fractions of the plant Zapoteca portoricensis root exhibited some protective effect against the development of $\mathrm{BPH}$, in addition to oxidative stress/lipid peroxidation and antioxidant capacity as shown in the increased levels of SOD, CAT and GSH and decreased levels of PSA, ACP and MAD. These observations are indications of modulatory effects of Zapoteca portoricensis root extracts on induced benign prostate hyperplasia (BPH) in male albino rats and could be a source of new agent for managing BPH.

Conflicts of Interest: The authors declare no conflict of interest in this work. 
The 1st International Electronic Conference on Antioxidants in Health and Disease, 1-15 December 2020

\section{References}

1. Zabaiou, N.; Mabed, D.; Lobaccaro, J.M.; Lahouel, M. Oxidative stress in benign prostate hyperplasia. Andrologia 2016, 48, 69-73.

2. Lee, M.Y.; Shin, I.S.; Lee, N.H.; Ha, H.; Kim, J.H.; Seo, C.S.; Shin, H.K. Effect of platycodon grandiflorum methanolic extract on testosterone-induced benign prostatic hyperplasia in wister rats. Afr. J. Biotechnol. 2012, 11, 4186-14192.

3. Lee, M.-Y.; Shin, I.-S.; Seo, C.-S.; Lee, N.-H.; Ha, H.-K.; Son, J.-K.; Shin, H.-K. Effects of Melandrium firmum methanolic extract on testosterone-induced benign prostatic hyperplasia in Wistar rats. Asian J. Androl. 2012, 14, 320-324.

4. Bhavin, A.V.; Niket, Y.D.; Dinesh, R.S. Effect of Boerhaavia diffusa in experimental prostatic hyperplasia in rate. Indian J. Pharmacol. 2013, 45, 264-269.

5. Roumeguère, T.; Sfeir, J.; El Rassy, E.; Albisinni, S.; Van Antwerpen, P.; Zouaoui Boudjeltia, K.; Farès, N.; Kattan, J.; Aoun, F. Oxidative stress and prostatic diseases. Mol. Clin. Oncol. 2017, 7, 723-728.

6. Ezeanyika, L.U.S.; Ejike, C.E.C.C.; Obidoa, O.; Elom, S.O. Prostate disorders in an apparent normal Nigerian population: Prevalence. Biokemistri 2006, 18, 127-132.

7. Ejike, C.E.; Ezeanyika, L.U.S. Metabolic syndrome in sub-Saharan Africa smaller twin of a regions prostatic disease. Int. Urol. Nephrol. 2008, 40, 909-920.

8. Akinyemi, R.A.; Huthman, I.O.; Adesanya, O.A.; Akpan, H.B.; Adefule, A.K. Effect of the methanolic extract of Trichosanthes cucumerina seed (Snake Gourd/Tomatoe) on experimentally enlarged prostate gland in adult wistar rats.Res. Rev. J. Med Health Sci. 2012, 1, 10-17.

9. Udensi, U.K.; Tchounwou, P.B. Oxidative stress in prostate hyperplasia and carcinogenesis. J. Exp. Clin. Cancer Res. 2016, 35, 1-19.

10. National Institute of Diabetes and Digestive and Kidney Disease (NIDDK), 2014. Available online: www.niddk.nih.gov/health-information/health-topics/urological-diseases/benign-prostatic-hyperplasia-bph/pa ges/facts (accessed on 17 July 2018).

11. Eleazu, C.; Eleazu, K.; Kalu, W. Management of Benign Prostatic Hyperplasia: Could Dietary Polyphenols Be an Alternative to Existing Therapies? Front. Pharmacol. 2017, 8, 234.

12. Wilt, T.J.; Ishani, A.; Rutks, I.; Macdonald, R. Phytotherapy for Benign Prostatic Hyperplasia. Public Health Nutr. 2000, 3, 459-472.

13. Lowe, F.C. Phytotherapy in the management of Benign Prostatic Hyperplasia. Urology 2001, 58 (Suppl. 1), 71-76.

14. Ejike, C.E.; Ezeanyika, L.U.S. Management of experimental BPH in rats using a food based therapy containing Telfairia occidentalis seeds. Afr. J. Tradit. Complement. Altern. Med. 2011, 8, 398-40.

15. Agbafor, K.N.; Ogbanshi, M.E.; Akubugwo, E.I. Phytochemical screening, hepatoprotective and antioxidant effect of leaf extract of Zapoteca portoricensis. Adv. Biol. Sci. 2014, 4, 35-39.

16. Nwodo, N.J.; Omeje, E.O.; Brun, R. In Vitro-in Vivo studies on anti-trypanosomal potentials of Zapoteca portoricensis. Asian Pac. J. Trop. Med. 2009, 2, 25-29.

17. Matthias, O.A.; Festus, B.C.O.; Justina, N.N. In vivo Anti-Inflammatory Effect of Zapoteca portoricensis. Int. J. Health Res. 2010, 3, 29-35.

18. Nwodo, N.J.; Okoye, F.B.C.; Lai, D.; Debbab, A.; Brun, R.; Proksch, P. Two trypanocidal Dipeptides from the roots of Zapoteca portricensis (Fabaceae). Molecules 2014, 19, 5470-5477.

19. Nwodo, N.J.; Uzochukwu, I.C. Studies on anti-inflammatory and antimicrobial activities of crude methanol extracts of Zapoteca portoricensis Jacq. H. Hernandez. Recent Prog. Med. Plants 2008, 19, 61-69.

20. Sahni, S.K. Guidelines for the Use of Laboratory Animals in Medical Colleges; Indian Council of Medical Research, New Delhi, Indian, 2001; pp. 6-19.

21. Sun, H.; Li, T.J.; Sun, L.N.; Qiu, Y.; Huang, B.B.; Yi, B.; Chen, W.S. Inhibitory effect of traditional Chinese medicine Zi-Shen Pill on benign prostatic hyperplasia in rats. J. Ethnopharmacol. 2008, 115, 203-208.

22. Nandecha, C.; Nahata, A.; Dixit, V.K. Effect of Benincasa hispida fruits on testosterone-induced prostatic hypertrophy in albino rats. Curr. Ther. Res. 2010, 71, 331-343.

23. Babu, S.V.V.; Veeresh, B.; Patil, A.A.; Warke, Y.B. Lauric acid and myristic acid prevent testosterone induced prostatic hyperplasia in rats. Eur. J. Pharmacol. 2010, 626, 262-265.

24. Tietz, N.W. Clinical Guide to Laboratory Test, 3rd ed.; W.B. Saunders Company: Philadelphia, PA, USA, 1995; pp. $518-519$. 
The 1st International Electronic Conference on Antioxidants in Health and Disease, 1-15 December 2020

25. Wallin, B.; Rosengren, B.; Shertzer, H.G.; Camejo, G. Lipoprotein oxidation and measurement of TBARS formation in single microlitre plate, it's use for evaluation of antioxidants. Anal. Biochem. 1993, 08, 10-15.

26. Arthur, J.R.; Boyne, R. Superoxide dismutase and glutathione peroxidase activities in neutrophil from selenium deficient and copper deficient cattle. Life Sci. 1985, 36, 1569-1575.

27. Sinha, K.A. Colorimetric Assay of Catalase. Ann. Biochem. 1972, 47, 389-394.

28. King, E.J.; Wootton, I.D.P. Microanalysis in Medical Biochemistry, 4th ed.; AJ Churchill: London, UK, $1959 ;$ p. 14.

29. Tietz, N.W. Methods for the determination of ascorbic acid. In Textbook of Clinical Chemistry; Kay, D., Kilmer, D., Eds.; W.B. Sunders company: Philadelphia, PA, USA, 1983; pp. 932-9333.

30. Joshua, P.E.; Ezugwu, C.H.; Chilaka, F.C.; Nwodo, O.F.C.; Dasofunjo, K.; Ezugwu, M.U. Effect of ethanol extract of Zapoteca portoricensis stem on testosterone-induced benign prostate hyperplasia (BPH) in adult male albino rats. Aust. J. Basic Appl. Sci. 2018, 12, 9-18.

31. Olamide, A.A.; Olayemi, O.O.; Demetrius, O.O.; Olatoye, O.J.; Kehinde, A.A. Effects of Methanolic Extract of Citrullus lanatus Seed on Experimentally Induced Prostatic Hyperplasia. Eur. J. Med. Plants 2011, 1, 171-179.

32. Mbaka, G.O.; Ogbonnia, S.O.; Olawunmi, O. The effects of ethanol extract of Raphia hookeri seed on exogenous testosterone and estradiol induced benign prostatic hyperplasia in adult male rats. J. Morphol. Sci. 2013, 30, 235-243.

33. Iweala, E.E.J.; Ogidigo, J.O. Prostate Specific Antigen, Antioxidant and Hematological Parameters in Prostatic Rats Fed Solanum macrocarpon L. Leaves. Asian J. Biol. Sci. 2015, 8, 30-41.

34. Iweala, E.E.J.; Ogidigo, J.O. Effect of Celosia argentea F. Cristata (L.) Schinz. on Prostate Specific Antigen, Antioxidant Status and Hematological Parameters in Rats Induced with Benign Prostate Hyperplasia. Asian J. Biochem. 2015, 10, 42-51.

35. Aydin, A.; Arsova-Sarafinovska, Z.; Sayal, A.; Eken, A.; Erdem, O.; Erten, O.; Ozok, Y.; Dimovski, A. Oxidative stress and antioxidant status in non-metastatic prostate cancer and benign prostatic hyperplasia. Clin. Biochem. 2006, 39, 176-179.

36. Esterbauer, H.; Schaur, R.J.; Zollner, H. Chemistry and biochemistry of 4-hydroxynonenal, malonaldehyde and related aldehydes. Free Radic. Biol. Med. 1991, 11, 81-128.

37. Johnson, F.; Giulivi, C. Superoxide dismutases and their impact upon human health. Mol. Asp. Med. 2005, 26, 340-352.

38. Chelikani, P.; Fita, I.; Loewen, P. Diversity of structures and properties among catalases. Cell. Mol. Life Sci. 2004, 61, 192-208.

39. Kramer, B.K.; Pults, V.M.; McCornic, J.M. Vitamin C analysis. Last update 2006, 102, 48-50.

40. Williams, L.; Leaper, D. Nutrition and wound healing. Clin. Update 2005, 5, 3-5.

41. Adachukwu P.I.; Lawrence.U.S.E.; Edwin, O.A.; Innocent.U.O. Proximate and Phytochemical compositions, and toxicity studies on Zapoteca portoricensis roots methanol extract and its fractions. Pharmacol. 2019, 1, 50-56.

Publisher's Note: MDPI stays neutral with regard to jurisdictional claims in published maps and institutional affiliations.

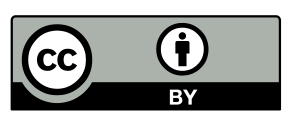

(C) 2020 by the authors; licensee MDPI, Basel, Switzerland. This article is an open access article distributed under the terms and conditions of the Creative Commons by Attribution (CC-BY) license (http://creativecommons.org/licenses/by/4.0/). 